\title{
Chemical Constituents from Aphanamixis grandifolia
}

\author{
Quan Liv, ${ }^{a}$ Chao-Jun Chen, ${ }^{a}$ Xiang ShI, ${ }^{b}$ Li Zhang, ${ }^{a}$ Hui-Juan Chen,,${ }^{a}$ and Kun GaO ${ }^{*}, a$ \\ ${ }^{a}$ State Key Laboratory of Applied Organic Chemistry, College of Chemistry and Chemical Engineering, Lanzhou \\ University; and ${ }^{b}$ School of Life Sciences, Lanzhou University; Lanzhou 730000, People's Republic of China. \\ Received March 9, 2010; accepted August 6, 2010; published online August 31, 2010
}

(23E)-25-Methylcycloart-23-en-3 $\beta$-ol (1), a cycloartane-type triterpenoid featuring an unusual skeleton of 31 carbon atoms, $(17 E)$-cycloart-17,26-dien-3 $\beta$-ol (2), a new cycloartane-type triterpenoid, and the other two new compounds $4 R$-hydroxy-4-(9S-hydroxy-12-methylhexan-6-yl)-3-methylcyclopent-2-enone (6) and 7-hydroxy5-(2'-hydroxy-4',5'-dimethoxyphenyl)-2-methoxy-6-methyl-1,4-naphthoquinone (7), together with three known cycloart-3 $\beta$-ol triterpenoids (3-5) were isolated from aerial parts of Aphanamixis grandifolia. Their structures were elucidated by spectroscopic analysis, and that of 1 was confirmed by single-crystal X-ray diffraction. The absolute configuration of two carbon stereocenters of compound 6 was determined to be $4 R, 9 S$ by means of circular dichroism (CD) and auxiliary chiral $\alpha$-methoxy- $\alpha$-(trifluoromethyl)phenylacetic acid (MTPA) derivatives, respectively. The compound 3 exhibited significant cytotoxicities against HL-60, Hep G2 and HeLa, and compounds $1,2,5,6$ and 7 exhibited modest cytotoxicities. No activity of compound 4 could be due to the absence of the hydroxyl group at C-24.

Key words Aphanamixis grandifolia; cycloartane-type triterpenoid; cyclopent-2-enone; 1,4-naphthoquinone; cytotoxicity

The genus Aphanamixis (Meliaceae) comprising about 5 species and varieties is mainly distributed in China, India and Indonesia. Aphanamixis grandifolia, an arbor tree mainly growing in southern China, is a medicinal plant employed as an astringent for spleen, liver, tumors, abdominal diseases, and applied in treatment of rheumatism in southeast Asia. ${ }^{1}$ It has not been chemically studied previously. In our current study, four new compounds $(\mathbf{1}, \mathbf{2}, \mathbf{6}, \mathbf{7})$ and three known compounds (3-5) were isolated from aerial parts of Aphanamixis grandifolia collected from Hainan Province, People's Republic of China. The structures of the new compounds were characterized using spectroscopic methods, and the structure of compound $\mathbf{1}$ was confirmed by single-crystal $\mathrm{X}$-ray diffraction analysis. The known compounds were elucidated by comparing their spectroscopic data with those reported in the literature. Their structures were identified as (23E)-25-methylcycloart-23-en-3 $\beta$-ol (1), a novel triterpenoid possessing a $\mathrm{C}_{31}$ skeleton, $(17 E)$-cycloart-17,26-dien$3 \beta$-ol (2), (23E)-cycloart-23-en-3 $\beta, 25$-diol (3), ${ }^{2)}(23 E)$ - 25 methoxycycloart-23-en-3 $\beta$-ol (4), ${ }^{2}$ cycloart-3 $\beta, 25$-diol (5), ${ }^{3)}$ $4 R$-hydroxy-4-(9S-hydroxy-12-methylhexan-6-yl)-3-methylcyclopent-2-enone (6), and 7-hydroxy-5-(2'-hydroxy-4',5'dimethoxyphenyl)-2-methoxy-6-methyl-1,4-naphthoquinone (7). In addition, the cytotoxicities of the compounds were evaluated against selected cancer cell lines, including human leukaemia cell (HL-60), human hepatoma cell (Hep G2), and human cervical carcinoma cell (HeLa) lines. The compound 3 was active (HL60 cell, $\mathrm{IC}_{50}=5.97 \mu \mathrm{g} / \mathrm{ml}$; Hep G2, $\mathrm{IC}_{50}=$ $20.85 \mu \mathrm{g} / \mathrm{ml} ; \mathrm{HeLa}, \mathrm{IC}_{50}=24.89 \mu \mathrm{g} / \mathrm{ml}$ ), compounds $\mathbf{1}, \mathbf{2}, \mathbf{5}$, $\mathbf{6}$ and $\mathbf{7}$ exhibited modest cytotoxicities. Herein we report the isolation, structural elucidation, and biological activities of these compounds.

\section{Results and Discussion}

The ethanolic extract of the aerial parts of Aphanamixis grandifolia was concentrated under vacuum and then subjected repeatedly to column chromatography over silica gel, Sephadex LH-20, and MCI yield compounds $\mathbf{1 - 7}$ (Chart 1).

The ${ }^{1} \mathrm{H}-\mathrm{NMR}$ spectra of compounds $\mathbf{1}-\mathbf{5}$ indicated the

presence of a cycloartane skeleton with $3 \beta$-ol group on C-3. ${ }^{2)}$ This fact was evidenced by the typical H-19 doublets at $\delta_{\mathrm{H}}$ $0.33(J=3.9 \mathrm{~Hz})$ and $0.55(J=3.9 \mathrm{~Hz})$, and the oxygenated methine near at $\delta_{\mathrm{H}} 3.30(\mathrm{~m})$. Comparison of the ${ }^{13} \mathrm{C}-\mathrm{NMR}$ spectra of $\mathbf{1}-\mathbf{5}$ with those of related cycloart-3 $\beta$-ol compounds in the literature, ${ }^{2)}$ the methylene of C-19 at $\delta_{\mathrm{C}} 30.0$ and the methine of C-3 at $\delta_{\mathrm{C}} 78.8$, confirmed that these were all $3 \beta$-hydroxycycloartanes.

Compound $\mathbf{1}$ was obtained as a colorless crystal. The high resolution-electronspray ionization-mass spectra (HR-ESIMS) displayed a molecular ion peak at $\mathrm{m} / z 441.4100$ [M+ $\mathrm{H}]^{+}$(Calcd for $\mathrm{C}_{31} \mathrm{H}_{53} \mathrm{O}, 441.4096$ ) consistent with a molecular formula of $\mathrm{C}_{31} \mathrm{H}_{52} \mathrm{O}$, requiring seven degrees of unsaturation, which was confirmed by ${ }^{13} \mathrm{C}-\mathrm{NMR}$ and distortionless enhancement by polarization transfer (DEPT) analysis. The ${ }^{13} \mathrm{C}$-NMR spectrum indicated 31 resonances ascribed to seven tertiary methyl, one secondary methyl, ten methylene, seven methine (one oxygenated and two $s p^{2}$ hybridized), and six quarternary carbon atoms, which indicated that compound 1 was a pentacyclic triterpenoid possessing a double bond $\left(\delta_{\mathrm{C}} 125.6,139.4\right)$ and one oxygen-bearing functional group. The ${ }^{1} \mathrm{H}$ - and ${ }^{13} \mathrm{C}-\mathrm{NMR}$ data of $\mathbf{1}$ were similar to those of 3, a cycloartane-type triterpenoid skeleton. The MS and ${ }^{1} \mathrm{H}-\mathrm{NMR}$ data revealed that $\mathbf{1}$ contained one more methyl singlet $\left(\delta_{\mathrm{H}} 1.33, \mathrm{~s} ; \delta_{\mathrm{C}} 29.9\right)$ than $\mathbf{3}$. In addition, the significant
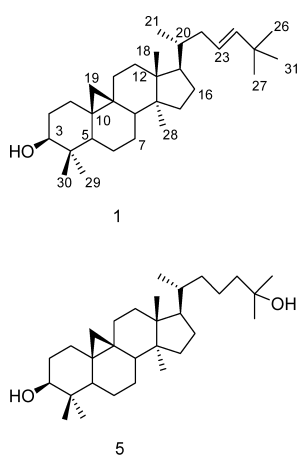

5
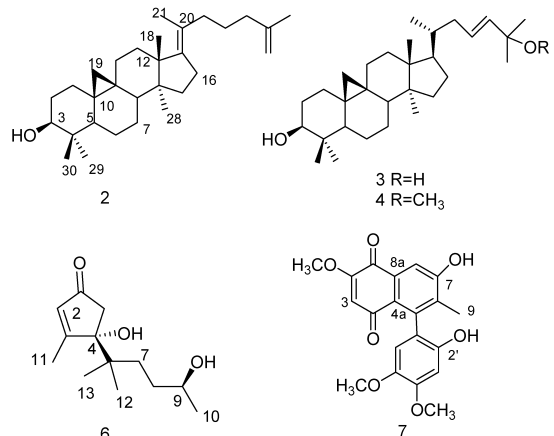

Chart 1

* To whom correspondence should be addressed. e-mail: npchem@1zu.edu.cn 


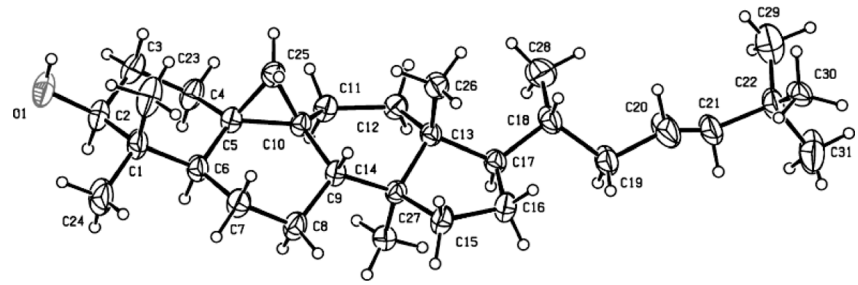

Fig. 1. Single-Crystal X-Ray Structure of $\mathbf{1}$

difference in the ${ }^{13} \mathrm{C}$-NMR spectra of $\mathbf{1}$ and $\mathbf{3}$ was that one quarternary carbon carbon at $\delta_{\mathrm{C}} 40.5$ (C) appeared in 1 instead of a downfield oxygenated carbon at $\delta_{\mathrm{C}} 70.8(\mathrm{C})$ in $\mathbf{3}$. The methyl of $\mathrm{C}-31$ should be linked at $\mathrm{C}-25$, due to the evident that the $\mathrm{H}-26$ and $\mathrm{H}-27\left(\delta_{\mathrm{H}} 1.33\right.$, s) were also tertiary methyl. In the ${ }^{1} \mathrm{H}-\mathrm{NMR}$ spectrum two proton signals assigned to a 1,2-disubstituted double bond appeared at $\delta_{\mathrm{H}}$ $5.60(2 \mathrm{H}, \mathrm{br})$. It was also supported by the ${ }^{13} \mathrm{C}$-NMR spectrum, where signals were observed at $\delta_{\mathrm{C}} 125.6$ and 139.3 . The olefinic proton signals of a trans-double bond were usually overlapped in $\mathrm{CDCl}_{3}$ solution in cycloart-23-en-25-ol derivatives, which was verified by Takahashi et al. ${ }^{4)} \mathrm{Com}-$ pared with the reported data, ${ }^{2,4}$ the stereochemistry of the double bond should be $E$. The structure of 1 was further confirmed by the single-crystal X-ray diffraction (Fig. 1). Compound 1 was established to be (23E)-25-methylcycloart-23en-3 $\beta$-ol. To our knowledge, the cycloartane triterpenoids were widely distributed in natural sources, but the cycloartane derivatives with the skeleton of 31 carbon atoms was rare.

Compound 2 was an optically active, $[\alpha]_{\mathrm{D}}^{20}+11(c=0.2$, $\mathrm{CHCl}_{3}$ ), amorphous solid. The molecular formula was determined as $\mathrm{C}_{30} \mathrm{H}_{48} \mathrm{O}$ by HR-ESI-MS $\left(\mathrm{m} / z 425.3775[\mathrm{M}+\mathrm{H}]^{+}\right.$, Calcd for 425.3778) associated with NMR data (Table 1) and indicated seven degrees of unsaturation. The ${ }^{13} \mathrm{C}$-NMR and DEPT spectra showed 30 carbon resonances including six tertiary methyl $\left(\delta_{\mathrm{C}} 13.9,18.2,20.0,25.4,29.4,30.4\right)$, twelve methylene (one olefinic at $\delta_{\mathrm{C}} 114.0$ ), three methine (one oxymethine at $\delta_{\mathrm{C}} 78.8$ ), and seven quaternary carbons (three olefinic at $\left.\delta_{\mathrm{C}} 129.7,134.0,142.3\right)$. These data, when they coupled with the information from the ${ }^{1} \mathrm{H}-\mathrm{NMR}$ spectrum [six tertiary methyl $\left(\delta_{\mathrm{H}} 0.81,0.85,0.96,0.96,1.25,1.31\right)$, two olefinic protons at $\delta_{\mathrm{H}} 5.59(\mathrm{brs}), 5.60(\mathrm{brs})$, and one oxymethine proton at $\delta_{\mathrm{H}} 3.15(\mathrm{~m})$ ], indicated that compound 2 was based on a cycloartane triterpenoid skeleton. The ${ }^{1} \mathrm{H}-$ NMR spectrum showed two olefinic signals at $\delta_{\mathrm{H}} 5.59(\mathrm{brs})$ and $5.60(\mathrm{brs})$, and the chemical shifts corresponded to two double bonds with three quaternary carbons at $\delta_{\mathrm{C}} 142.3$, $134.0,129.7$ and a $s p^{2}$ methylene carbon at $\delta_{\mathrm{C}} 114.0$ in the ${ }^{13} \mathrm{C}$-NMR and DEPT experiments. OH- 3 was assigned $\beta$-orientations because of the nuclear overhauser effect (NOE) correlation between $\mathrm{H}-3\left(\delta_{\mathrm{H}} 3.28\right)$ and $\mathrm{H}-5 \mathrm{~b}\left(\delta_{\mathrm{H}} 1.68\right)$. A computer modeled 3D structure of $\mathbf{2}$ was generated by using MM2 force field calculations for energy minimization with the molecular modeling program Chem3D Ultra 9.0. The relative stereochemistry and the conformation of $\mathbf{2}$ assigned by NOE spectrums were compatible with those of $\mathbf{2}$ offered by computer modeling, in which the close contacts of atoms calculated in space were consistent with the NOE correlations. Therefore, and in view of biogenetic consideration, the structure of 2 was identified as (17E)-cycloart-17,26-dien-3 $\beta$-ol.
Table 1. NMR Data of Compounds $\mathbf{1}-\mathbf{3}$ in $\mathrm{CDCl}_{3}(J$ in $\mathrm{Hz})$

\begin{tabular}{|c|c|c|c|c|c|}
\hline \multirow{2}{*}{ Carbon } & \multicolumn{3}{|c|}{1} & 2 & 3 \\
\hline & $\delta_{\mathrm{C}}$ & $\delta_{\mathrm{H}}(J$ in $\mathrm{Hz})$ & $\delta_{\mathrm{C}}$ & $\delta_{\mathrm{H}}(J$ in $\mathrm{Hz})$ & $\delta_{\mathrm{C}}$ \\
\hline 1 & 32.0 & $\begin{array}{l}1.48(\mathrm{~m}) \\
1.52(\mathrm{~m})\end{array}$ & 32.7 & $\begin{array}{l}1.39(\mathrm{~m}) \\
1.48(\mathrm{~m})\end{array}$ & 32.0 \\
\hline 2 & 30.4 & $\begin{array}{l}1.42(\mathrm{~m}) \\
1.57(\mathrm{~m})\end{array}$ & 32.0 & $\begin{array}{l}1.43(\mathrm{~m}) \\
1.55(\mathrm{~m})\end{array}$ & 30.4 \\
\hline 3 & 78.8 & $3.30(\mathrm{~m})$ & 78.8 & $3.28(\mathrm{~m})$ & 78.8 \\
\hline 4 & 40.5 & & 39.7 & & 40.5 \\
\hline 5 & 47.1 & $1.70(\mathrm{~m})$ & 47.1 & $1.68(\mathrm{~m})$ & 47.1 \\
\hline 6 & 21.1 & $\begin{array}{l}1.96(\mathrm{~m}), \\
1.93(\mathrm{~m})\end{array}$ & 21.1 & $\begin{array}{l}1.98(\mathrm{~m}) \\
1.92(\mathrm{~m})\end{array}$ & 21.1 \\
\hline 7 & 26.0 & $1.36(\mathrm{~m})$ & 26.1 & $1.29(\mathrm{~m})$ & 26.0 \\
\hline 8 & 47.9 & $1.81(\mathrm{~m})$ & 48.0 & $1.85(\mathrm{~m})$ & 47.9 \\
\hline 9 & 20.0 & & 18.8 & & 20.0 \\
\hline 10 & 26.1 & & 26.1 & & 26.1 \\
\hline 11 & 26.4 & $\begin{array}{l}1.26(\mathrm{~m}) \\
1.60(\mathrm{~m})\end{array}$ & 26.4 & $\begin{array}{l}1.35(\mathrm{~m}) \\
1.58(\mathrm{~m})\end{array}$ & 26.4 \\
\hline 12 & 32.8 & $\begin{array}{l}0.90(\mathrm{~m}) \\
1.64(\mathrm{~m})\end{array}$ & 35.6 & $\begin{array}{l}0.91(\mathrm{~m}) \\
1.63(\mathrm{~m})\end{array}$ & 32.8 \\
\hline $\begin{array}{l}13 \\
14\end{array}$ & $\begin{array}{l}45.3 \\
48.8\end{array}$ & & $\begin{array}{l}45.3 \\
48.8\end{array}$ & & $\begin{array}{l}45.3 \\
48.8\end{array}$ \\
\hline 15 & 35.5 & $\begin{array}{l}1.36(\mathrm{~m}) \\
1.24(\mathrm{~m})\end{array}$ & 36.8 & $\begin{array}{l}1.35(\mathrm{~m}) \\
1.26(\mathrm{~m})\end{array}$ & 35.6 \\
\hline 16 & 28.0 & $1.28(\mathrm{~m})$ & 28.2 & $1.29(\mathrm{~m})$ & 28.1 \\
\hline 17 & 52.0 & $1.28(\mathrm{~m})$ & 134.0 & & 52.0 \\
\hline 18 & 18.1 & $0.98(\mathrm{~s})$ & 18.1 & $0.92(\mathrm{~m})$ & 18.0 \\
\hline 19 & 30.0 & $\begin{array}{l}0.33(\mathrm{~d}, J=3.9) \\
0.56(\mathrm{~d}, J=3.9)\end{array}$ & 29.9 & $\begin{array}{l}0.33(\mathrm{~d}, J=3.6) \\
0.55(\mathrm{~d}, J=3.6)\end{array}$ & 29.9 \\
\hline 20 & 36.4 & $1.90(\mathrm{~m})$ & 129.7 & & 36.4 \\
\hline 21 & 18.3 & $0.86(\mathrm{~d}, J=6.5)$ & 30.4 & 1.31 (brs) & 18.2 \\
\hline 22 & 39.0 & $2.16(\mathrm{~m})$ & 52.2 & $2.03(\mathrm{~m})$ & 39.0 \\
\hline 23 & 125.6 & $5.60(\mathrm{brs})$ & 18.2 & $1.31(\mathrm{~m})$ & 125.6 \\
\hline 24 & 139.4 & $5.60(\mathrm{brs})$ & 40.5 & $1.98(\mathrm{~m})$ & 139.3 \\
\hline 25 & 40.5 & & 142.3 & & 70.8 \\
\hline 26 & 30.0 & $1.33(\mathrm{~s})$ & 114.0 & $\begin{array}{l}5.59 \text { (brs), } \\
5.60(\mathrm{brs})\end{array}$ & 29.9 \\
\hline 27 & 30.0 & $1.33(\mathrm{~s})$ & 29.7 & $1.25(\mathrm{~s})$ & 29.9 \\
\hline 28 & 19.3 & $0.85(\mathrm{~s})$ & 20.0 & $0.81(\mathrm{~s})$ & 19.2 \\
\hline 29 & 25.4 & $0.88(\mathrm{~s})$ & 25.4 & $0.96(\mathrm{~s})$ & 25.4 \\
\hline 30 & 14.0 & $0.88(\mathrm{~s})$ & 13.9 & $0.96(\mathrm{~s})$ & 13.9 \\
\hline 31 & 29.9 & $1.33(\mathrm{~s})$ & & & \\
\hline
\end{tabular}

The double bond located at 17 and 20, which was rare in natural resources and will enter into the architectural diversity of the cycloartane family.

Compound 6 displayed a molecular ion peak at $\mathrm{m} / \mathrm{z}$ 227.1649 (Calcd for 227.1647) in the HR-electron ionization (EI)-MS corresponding to the molecular formula of $\mathrm{C}_{13} \mathrm{H}_{22}$ $\mathrm{O}_{3}$. The IR absorption bands at 3392 and $1712 \mathrm{~cm}^{-1}$ indicated the presence of hydroxyl and carbonyl groups, respectively. The ${ }^{13} \mathrm{C}$-NMR data of compound 6 resolved 13 resonances attributable to four methyl groups, three methylene, two methane (one oxygenated and one olefinic), and four quaternary carbons $(\alpha, \beta$-unsaturated carbonyl and one oxygenated). The ${ }^{1} \mathrm{H}-{ }^{1} \mathrm{H}$ correlation spectroscopy (COSY) and heteronuclear multiple bond connectivity (HMBC) spectroscopic analyses of $\mathbf{6}$ revealed its planar structure and led to unambiguous assignments of the NMR data (Fig. 2). The absolute configuration of C-4 in $\mathbf{6}$ was determined from the circular dichroism (CD) spectrum (Fig. 3). On the basis of the octant rule for cyclopentanones and related reports, the positive Cotton effect at $330 \mathrm{~nm}\left(\Delta \varepsilon_{\max }=+0.76\right)$ for $n \rightarrow \pi^{*}$ and the negative Cotton effect at $246 \mathrm{~nm}\left(\Delta \varepsilon_{\max }=-5.61\right)$ for $\pi \rightarrow \pi^{*}$ indicated that the configuration at C-4 was as de- 


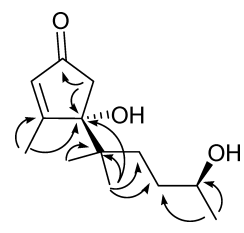

Fig. 2. Key HMBC Correlations of Compound $\mathbf{6}$

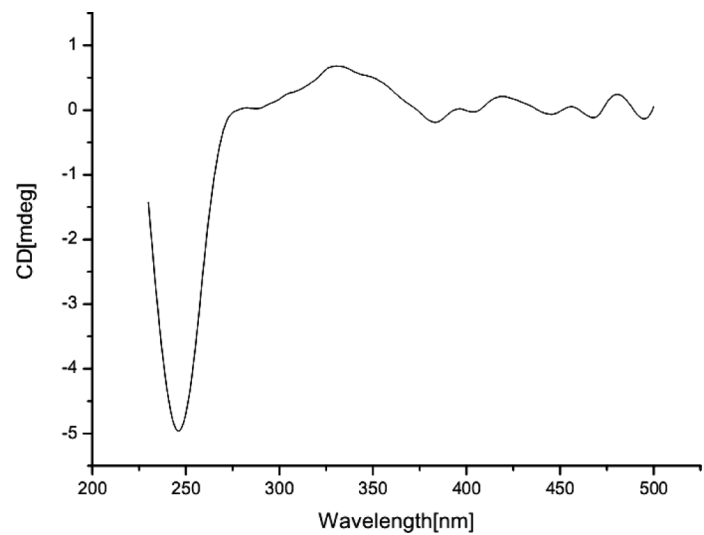

Fig. 3. CD Spectrum of Compound 6

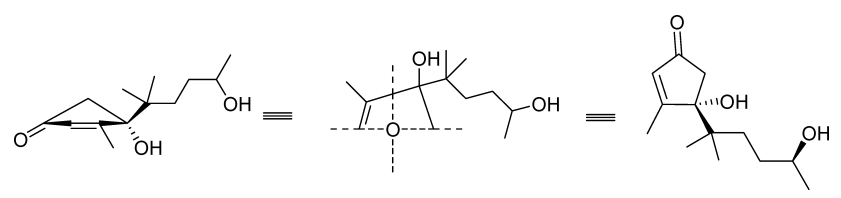

Fig. 4. Absolute Configuration of $\mathrm{C}-4$ in Compound 6

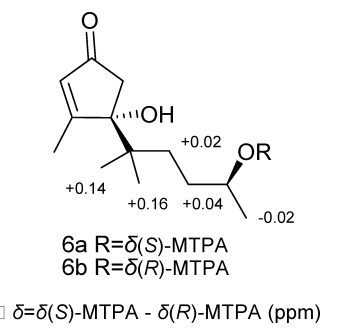

Fig. 5. ${ }^{1} \mathrm{H}-\mathrm{NMR}$ Chemical Shift Differences $[\delta(S)$-MTPA $-\delta(R)$-MTPA] of the MTPA Esters for Compound 6

picted in Fig. 4. Therefore, the absolute configuration at the chiral centers of C-4 was $4 R$. Compound 6 was treated with $(R)$ - and $(S)$ - $\alpha$-methoxy- $\alpha$-(trifluoromethyl)phenylacetic acid (MTPA)-Cl, and the $(S)$ - and (R)-MTPA esters at C-9 of 6 $(\mathbf{6 a}, \mathbf{6 b})$ were obtained, respectively. Comparison of the ${ }^{1} \mathrm{H}$ NMR chemical shifts for $\mathbf{6 a}$ and $\mathbf{6 b}$ ( $\Delta$ values shown in Fig. 5) led to the assignment of the $S$-configuration at C-9 in $\mathbf{6}$. Hence, the structure of compound 6 was elucidated as $4 R$-hydroxy-4-(9S-hydroxy-12-methylhexan-6-yl)-3-methylcyclopent-2-enone.

Compound 7 exhibited a molecular ion peak at $\mathrm{m} / \mathrm{z}$ 371.1136 (Calcd for 371.1131) in the HR-EI-MS indicating a molecular formula of $\mathrm{C}_{20} \mathrm{H}_{18} \mathrm{O}_{7}$. The IR spectrum of 7 showed absorptions at 3311 (hydroxy), 2923 ( $\alpha, \beta$-unsaturated carbonyl) and $1671 \mathrm{~cm}^{-1}$ (carbonyl). The UV spectrum showed absorption at 248, 286, and $318 \mathrm{~nm}$, resembling those of naphthoquinone derivatives, which was confirmed by the positive result in Magnesium Acetate test. The ${ }^{13} \mathrm{C}$ -

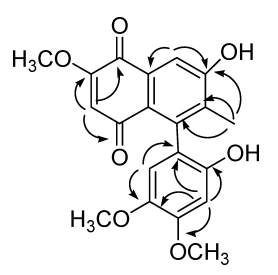

Fig. 6. Key HMBC Correlations of Compound 7

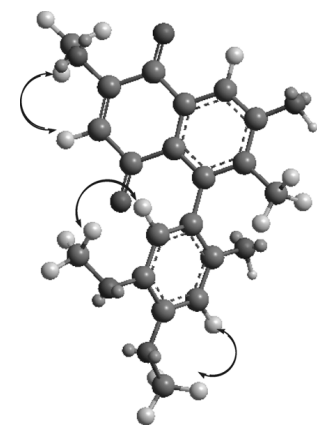

Fig. 7. Key NOE Correlations of Compound 7

NMR and DEPT spectrum revealed that 7 contains fourteen olefinic carbons, four methyl (three oxygenated) and two carbonyl groups. A comparison of its NMR data with those of 2-methoxy-5-(3,4-dimethoxyphenyl)-6-ethoxycarbonyl-7hydroxy-1,4-naphthoquinone, ${ }^{5)}$ indicated that 7 was an analogue of 1,4-naphthoquinones. The structure was determined by analysis of the HMBC data of 7 (Fig. 6). All methoxyl resonances were assigned by NOE correlations (Fig. 7). Finally, the structure of 7 was established as 7-hydroxy-5-(2'hydroxy-4',5'-dimethoxyphenyl)-2-methoxy-6-methyl-1,4naphthoquinone. The 1,4-naphthoquinone derivatives including vitamin $\mathrm{K}$, plumbagin (PL), juglone, and shikonin are well known to possess various pharmacologic properties. ${ }^{6)}$ To the best of our knowledge, the skeleton of 5-aryl-6-methyl1,4-naphthoquinone was synthesized artificially as a synthetic product, and rarely found in nature.

In in vitro cytotoxic assays using the sulforhodamine B (SRB) method $^{7)}$ against several human cancer cell lines including human leukemia (HL-60), human hepatoma (Hep G2), human cervical carcinoma (HeLa), compound 3 showed significant cytotoxicities against $\mathrm{HL}-60\left(\mathrm{IC}_{50}=5.97 \mu \mathrm{g} / \mathrm{ml}\right)$, Hep $\mathrm{G} 2\left(\mathrm{IC}_{50}=20.85 \mu \mathrm{g} / \mathrm{ml}\right)$ and $\mathrm{HeLa}\left(\mathrm{IC}_{50}=24.89 \mu \mathrm{g} / \mathrm{ml}\right)$, compounds 1, 2, 5, 6 and 7 exhibited modest cytotoxicity (Table 4). Comparing with compounds 1, 2, $\mathbf{3}$ and $\mathbf{5}$, the lack of activity of compound $\mathbf{4}$ could be caused by the absence of the hydroxyl group on $\mathrm{C}-24$, in spite of the existence of the cycloartane skeleton.

\section{Experimental}

General Experimental Procedures IR spectra were recorded on a Nicolet 170SX Fourier transform-infrared (FT-IR) instrument using $\mathrm{KBr}$ discs over the range $400-4000 \mathrm{~cm}^{-1}$. UV detections were measured on a Shimadzu UV-260 spectrophotometer. NMR spectra were obtained on a Bruker AM-400 and a Varian Mercury-300/400BB NMR spectrometer with tetramethylsilane (TMS) as an internal standard in $\mathrm{CDCl}_{3}$. HR-ESI-MS were obtained on a Bruker Daltonics APEX-II 47e spectrometer. EI-MS data were obtained on an HP5988AGCMS spectrometer. HR-ESI-MS data were measured on a Bruker Daltonics APEX II 47e spectrometer. The X-ray crystallographic data were collected on a Bruker Smart CCD diffractometer using graphic-monochro-mate $\mathrm{Mo} K \alpha$ radiation. Analytical and preparative thinlayer chromatographys (TLC) were performed on silica gel plates $\left(\mathrm{GF}_{254}\right.$ 
Table 2. NMR Data of Compound 6 in $\mathrm{CDCl}_{3}(J$ in $\mathrm{Hz})$

\begin{tabular}{rll}
\hline \hline & $\delta_{\mathrm{C}}$ & \multicolumn{1}{c}{$\delta_{\mathrm{H}}(J$ in Hz $)$} \\
\hline 1 & 198.1 & $5.85(\mathrm{~s})$ \\
2 & 126.0 & \\
3 & 168.3 & $2.2(\mathrm{~d}, J=18.0), 2.5(\mathrm{~d}, J=18.0)$ \\
4 & 77.8 & $1.85(\mathrm{~m}), 1.95(\mathrm{~m})$ \\
5 & 34.8 & $1.54(\mathrm{~m}), 1.62(\mathrm{~m})$ \\
6 & 41.7 & $3.79(\mathrm{~m})$ \\
7 & 49 & $1.23(\mathrm{~d}, J=6.3)$ \\
8 & 33.5 & $2.05(\mathrm{~s})$ \\
9 & 68.7 & $1.09(\mathrm{~s})$ \\
10 & 21.8 & $1.05(\mathrm{~s})$ \\
11 & 24.2 & \\
12 & 23.8 &
\end{tabular}

Table 3. NMR Data of Compound 7 in $\mathrm{CDCl}_{3}(J$ in $\mathrm{Hz})$

\begin{tabular}{ccc}
\hline \hline & $\delta_{\mathrm{C}}$ & $\delta_{\mathrm{H}}$ \\
\hline 1 & 185.2 & \\
2 & 160.7 & \\
3 & 125.5 & $6.14(\mathrm{~s})$ \\
4 & 181.0 & \\
$4 \mathrm{a}$ & 128.1 & \\
5 & 123.8 & \\
6 & 128.5 & \\
7 & 158.6 & $7.99(\mathrm{~s})$ \\
8 & 108.7 & \\
$8 \mathrm{a}$ & 124.4 & \\
9 & 16.0 & \\
$1^{\prime}$ & 114.8 & \\
$2^{\prime}$ & 153.7 & \\
$3^{\prime}$ & 94.5 & \\
$4^{\prime}$ & 146.0 & \\
$5^{\prime}$ & 151.8 & $(\mathrm{~s})$ \\
$6^{\prime}$ & 108.5 & $3.96(\mathrm{~s})$ \\
$2^{\prime}-\mathrm{OMe}$ & $56.4^{a)}$ & $4.02(\mathrm{~s})$ \\
$4^{\prime}-\mathrm{OMe}$ & $56.6^{a}$ & \\
$5^{\prime}-\mathrm{OMe}$ & $56.5^{a}$ & \\
& & \\
\hline
\end{tabular}

a) Signals within same column may be interchangeable.

10- $40 \mu \mathrm{m}$, Qingdao Marine Chemical Factory). Analytical TLC was provided to follow the separation and check the purity of isolated compounds Spots on the plates were observed under UV light at $254 \mathrm{~nm}$ and visualized by spraying them with $5 \% \mathrm{H}_{2} \mathrm{SO}_{4}$ in $\mathrm{EtOH}(\mathrm{v} / \mathrm{v})$, followed by heating. Column chromatography (CC) was performed on silica gel (200-300 mesh, Qingdao Marine Chemical Factory). The spots were detected on TLC by heating to $90{ }^{\circ} \mathrm{C}$ after spraying with $0.5 \%$ Magnesium Acetate in $\mathrm{CH}_{3} \mathrm{OH}$ $(\mathrm{v} / \mathrm{v})$ in the Magnesium Acetate test.

Plant Material The aerial parts of Aphanamixis grandifolia were collected in Tuncang County of Hainan Province, China, July 2007, and identified by Qiongxin Zhong of Hainan Normal University. The voucher specimen (No. 2007006) was deposited in the State Key Laboratory of Applied Organic Chemistry, Lanzhou University, China.

Extraction and Isolation The air-dried, powdered aerial parts of $A$. grandifolia $(6.94 \mathrm{~kg})$, were extracted with a mixture of EtOH at room temperature. After evaporation of the solvent in vacuo, the residue $(498.1 \mathrm{~g})$ was fractionated on a silica gel column with a gradient mixture of petroleum ether- $\mathrm{Me}_{2} \mathrm{CO}$ and finally $\mathrm{MeOH}$ to give eight fractions (Fr. A-Fr. H). Fr. D was extensively separated over the columns of silica gel (PE: AcOEt, 20:1, $10: 1 ; \mathrm{CHCl}_{3}$ : AcOEt, $\left.60: 1\right)$ to give $1(8 \mathrm{mg}), 2(6 \mathrm{mg})$ and $4(3 \mathrm{mg})$. Fr. E was subjected to by chromatography on MCI (EtOH: $\mathrm{H}_{2} \mathrm{O}, 50 \%, 80 \%$, $100 \%$ ) and repeatly separated on silica gel columns, and then purified by chromatography on a Sephadex LH-20 column $\left(\mathrm{CHCl}_{3}: \mathrm{MeOH}, 1: 1\right)$ to afford 3 (32 mg), 5 (1 mg), 6 (6 mg), 7 (9 mg).

(23E)-25-Methylcycloart-23-en-3 $\beta$-ol (1): Colorless crystal, mp 248 $250^{\circ} \mathrm{C} .[\alpha]_{\mathrm{D}}^{20}+34\left(c=0.2, \mathrm{CHCl}_{3}\right)$; IR $(\mathrm{KBr}) v_{\max } 3395,2959,2855$ $1711,1458,1383,1047 \mathrm{~cm}^{-1} ;{ }^{1} \mathrm{H}$ - and ${ }^{13} \mathrm{C}-\mathrm{NMR}$ data (see Table 1); EI-MS
Table 4. Cytotoxicity Assay for Isolated Compounds 1-7

\begin{tabular}{cccc}
\hline \hline & \multicolumn{3}{c}{$\mathrm{IC}_{50}(\mu \mathrm{g} / \mathrm{ml})$} \\
\cline { 2 - 4 } & HL60 cell & Hep G2 cell & HeLa cell \\
\hline Mitomycin & $0.56 \pm 0.17$ & $1.85 \pm 0.53$ & $1.11 \pm 0.64$ \\
1 & $69.24 \pm 6.75$ & $82.63 \pm 7.52$ & $\mathrm{NE}$ \\
2 & $36.70 \pm 6.10$ & $50.54 \pm 6.35$ & $35.83 \pm 4.03$ \\
3 & $5.97 \pm 1.13$ & $20.85 \pm 3.80$ & $24.89 \pm 4.81$ \\
4 & $\mathrm{NE}$ & $\mathrm{NE}$ & $\mathrm{NE}$ \\
5 & $39.16 \pm 5.52$ & $55.69 \pm 3.43$ & $39.96 \pm 3.80$ \\
6 & $51.12 \pm 11.23$ & $85.44 \pm 0.80$ & $109.66 \pm 11.83$ \\
7 & $21.44 \pm 4.83$ & $86.75 \pm 9.36$ & $50.87 \pm 6.72$ \\
& & &
\end{tabular}

(pos.) $m / z 440[\mathrm{M}]^{+}$; HR-ESI-MS (pos.) $m / z 441.4100[\mathrm{M}+\mathrm{H}]^{+}$(Calcd for $\left.\mathrm{C}_{31} \mathrm{H}_{53} \mathrm{O}, 441.4096\right)$.

(17E)-Cycloart-17,26-dien-3 $\beta$-ol (2): Amorphous solid, $[\alpha]_{\mathrm{D}}^{20}+11(c=$ $\left.0.2, \mathrm{CHCl}_{3}\right)$; IR (KBr) $v_{\max } 3337,2923,2858,1709,1458,1379,1097$, $1026 \mathrm{~cm}^{-1}$; ${ }^{1} \mathrm{H}$ - and ${ }^{13} \mathrm{C}-\mathrm{NMR}$ data (see Table 1); EI-MS (pos.) $\mathrm{m} / \mathrm{z} 424$ $[\mathrm{M}]^{+}$; HR-ESI-MS (pos.) $m / z 425.3775[\mathrm{M}+\mathrm{H}]^{+}$(Calcd for $\mathrm{C}_{30} \mathrm{H}_{49} \mathrm{O}$, 425.3778).

4R-Hydroxy-4-(9S-hydroxy-12-methylhexan-6-yl)-3-methylcyclopent-2enone (6): Amorphous solid, $[\alpha]_{\mathrm{D}}^{20}-12\left(c=0.2, \mathrm{CHCl}_{3}\right)$; IR $(\mathrm{KBr}) v_{\max }$ 3392, 2964, 2875, 1711, 1652, 1456, 1379, $1051 \mathrm{~cm}^{-1}$; UV 246, 252, 258 and $330 \mathrm{~nm}$; ${ }^{1} \mathrm{H}$ - and ${ }^{13} \mathrm{C}-\mathrm{NMR}$ data (see Table 2); EI-MS (pos.) $\mathrm{m} / z 226$ $[\mathrm{M}]^{+}$; HR-ESI-MS (pos.) $\mathrm{m} / z 227.1649[\mathrm{M}+\mathrm{H}]^{+}$(Calcd for $\mathrm{C}_{13} \mathrm{H}_{23} \mathrm{O}_{3}$, 227.1647).

7-Hydroxy-5-(2'-hydroxy-4', 5'-dimethoxyphenyl)-2-methoxy-6-methyl1,4-naphthoquinone (7): Red solid, $[\alpha]_{\mathrm{D}}^{20}-4\left(c=0.2, \mathrm{CHCl}_{3}\right)$; IR $(\mathrm{KBr}) v_{\max }$ 3311, 2923, 2853, 1671, 1461, 1379, 1301, $1073 \mathrm{~cm}^{-1}$; UV 248, 286, and $318 \mathrm{~nm} ;{ }^{1} \mathrm{H}$ - and ${ }^{13} \mathrm{C}-\mathrm{NMR}$ data (see Table 3); EI-MS (pos.) $m / z 370[\mathrm{M}]^{+}$; HR-ESI-MS (pos.) $m / z 371.1136[\mathrm{M}+\mathrm{H}]^{+}$(Calcd for $\mathrm{C}_{20} \mathrm{H}_{19} \mathrm{O}_{7}, 371.1131$ ).

$(R)$ - and $(S)$-MTPA Derivatives of 6 To a solution of compound 6 $\left(2.0 \mathrm{mg}, 8.9 \times 10^{-3} \mathrm{mmol}\right)$ in (dimethylamino)pyridine $\left(5.3 \mathrm{mg}, 43.2 \times 10^{-3}\right.$ $\mathrm{mmol})$ and triethylamine $\left(4.5 \mu 1,31.5 \times 10^{-3} \mathrm{mmol}\right)$ at room temperature was added $(S)$-MTPA-Cl $\left(4.02 \mu 1,22.1 \times 10^{-3} \mathrm{mmol}\right)$, and the resultant mixture was stirred for $24 \mathrm{~h}$ at room temperature. The reaction mixture was worked up by adding $2 \mathrm{ml}$ of water. Further purification was performed with the columns of silica gel with petroleum ether-EtOAc, $5: 1$, to give the $(R)$ MTPA ester $\mathbf{6 b}(1.1 \mathrm{mg})$ as a colorless gum. The $(S)$-MTPA ester 6a (1.2 $\mathrm{mg}$ ) was prepared in a similar manner.

X-Ray Crystal Structure Analysis of $\mathbf{1}^{8)}$ A crystal of 1 with dimensions $0.35 \times 0.29 \times 0.24 \mathrm{~mm}$ was selected for X-ray analysis. Structure analysis was performed using the SHELEXTL-97 program on a PC. Data were collected over a hemisphere of reciprocal space, by a combination of three sets of exposures. The compound crystallized in the monoclinic space group $C 2$, with $a=33.814(2) \AA, b=7.4041(5) \AA, c=11.1212(8) \AA, \beta=98.276(6)^{\circ}$, $V=2755.4(3) \AA^{3}, Z=4, \quad D_{\text {calc }}=1.062 \mathrm{~g} / \mathrm{cm}^{3}, \quad \lambda=0.71073 \AA, \mu(\mathrm{MoK} \alpha)=$ $0.061 \mathrm{~mm}^{-1}, F(000)=984$, and $T=296(2) \mathrm{K}$. The SMART program was used to make data corrections. A total of 7899 reflections, collected in the range $1.22^{\circ} \leq \theta \leq 26.00^{\circ}$, yielded 4925 unique reflections. The structure was solved using direct methods and was refined by full-matrix least-squares on $F 2$ values for $4925 I>2 \sigma(I)$. Non-hydrogen atoms were refined anisotropically. Hydrogen atoms were fixed at calculated positions and refined using a riding mode. The final indices were $R=0.0770, R_{\mathrm{w}}=0.1898$ with goodnessof-fit $=1.045$. Scattering factors were taken from 'International Tables for Xray Crystallography. ${ }^{\text {9) }}$

Biological Activity The cytotoxicities of compounds 1-7 toward human leukaemia cell (HL-60), human hepatoma cell (Hep G2) and human cervical carcinoma cell (HeLa) lines were determined in 96-well microtiter plates by the sulforhodamine B method described by Skehan et al. ${ }^{7)}$ Briefly, exponentially growing cancer cells were harvested and seeded in 96-well plates with the final volume $100 \mu \mathrm{l}$ containing $4 \times 10^{3}$ cells per well. After $24 \mathrm{~h}$ incubation, cells were treated with various concentrations of these compounds for $48 \mathrm{~h}$. The cultures were fixed at $4{ }^{\circ} \mathrm{C}$ for $1 \mathrm{~h}$ by addition of icecold $50 \%$ trichloroacetic acid (TCA) to give a final concentration of $10 \%$. Fixed cells were rinsed 5 times with deionized water and stained for $10 \mathrm{~min}$ with $0.4 \%$ sulforhodamine B dissolved in $1 \%$ acetic acid. The wells were washed 5 times with $1 \%$ acetic acid and left to dry overnight. The absorbed sulforhodamine B was dissolved in $150 \mu$ l unbuffered $1 \%$ Tris base [tris(hydroxymethyl)aminomethane] solution in water ( $\mathrm{pH} 10.5)$. The absorbency of 
extracted sulforhodamine B at $515 \mathrm{~nm}$ was measured on a microplate reade (Bio-Rad). The experiments were carried out in triplicate. Each run entailed $5-6$ concentrations of the compounds being tested. The percentage survival rates of cells exposed to the compounds were calculated by assuming the survival rate of untreated cells to be $100 \%$.

Acknowledgment This work was funded by the Project No 2007CB108903 supported by the National Basic Research Program of China (973 Program) and the Projects No. 20972062 supported by the National Natural Science Foundation of China.

\section{References and Notes}

1) "Glossary of Indian Medicinal Plants," C.S.I.R. Publication, New Delhi, 1956, p. 21.

2) Cabrera G.-M., Gallo M., Seldes A.-M., J. Nat. Prod., 59, 343-347 (1996).

3) Gaspar E.-M., Neves H.-J., Phytochemistry, 34, 523 - 527 (1993).
4) Takahashi S., Satoh H., Hongo Y., Koshino H., J. Org. Chem., 72, 4578-4581 (2007).

5) Nechepurenko I.-V., Shul'ts E.-E., Tolstikov G.-A., Russian Journal of Organic Chemistry, 39, 1436-1450 (2003).

6) Sakamoto S., Taura F., Putalun W., Pongkitwitoon B., Tsuchihashi R., Morimoto S., Kinjo J., Shoyama Y., Tanaka H., Biol. Pharm. Bull., 32, 434-439 (2009).

7) Skehan P., Storeng R., Scudiero D., Monks A., McMahon J., Vistica D., Warren J. T., Bokesch H., Kenney S., Boyd M. R., J. Natl. Cancer Inst., 82, 1107-1112 (1990).

8) Crystallography data of $\mathbf{1}$ have been deposited with the Cambridge Crystallographic Data Center as supplementary publication number CCDC 761103.

9) “International Tables for X-Ray Crystallography," Vol. IV, ed. by Ibers J.-A., Hamilton, W.-C., The Kynoch Press, Birmingham, 1974. 